e-ISSN: 2623-0089

Website :

jurnal.umj.ac.id/index.php/baskara

Email : baskara@umj.ac.id

\title{
Social Entrepreneurship Communication of Kampung Teknologi Foundation through the Digital Literation of MSMEs during COVID-19 Pandemic
}

\author{
Sulistiyawati ${ }^{1}$, Nuriyati Samatan ${ }^{2}$ \\ ${ }^{1}$ Department of Marketing Communication, Gunadarma University, Depok \\ 2Department of Communication Studies, Gunadarma University, Depok \\ Jl. Margonda Raya No. 100, Depok, Jawa Barat 16424 \\ *E-mail: sulistw78@gmail.com
}

\begin{abstract}
Information and Communication Technology (ICT) is significant for developing human resources in various villages in the current digital era. However, the implementation of ICT has experienced disruption due to the increasing spread of the COVID-19 virus, resulting in a decline in market mechanisms, especially in the Village MSME sector. This paper aims to describe social innovation is needed by social entrepreneurs so that MSMEs can survive and compete with others, as has been done by the Kampung Teknologi Foundation (KTF) through digital literacy to MSMEs in villages. The method in this study used qualitative research using the Social Innovation Model. As a result, in social entrepreneurship communication, KTF carried out three essential stages, 1) Formalization: KTF used Law Number 6 of 2014 concerning Villages as a basis for empowering MSMEs. KTF initiated the empowerment of MSMEs in villages by introducing digital sales using social media, market places, e-commerce, and other digital applications; 2) Change processes: KTF implemented digital sales by initiating the Digital Up program, which is an entrepreneur empowerment program and was implemented after five-year KTF contributes to digital literacy; 3) Social Outcomes: In the application of digital literacy, only 30\% of MSMEs have successfully switched to using digital technology. Therefore, good cooperation between one division and another is still needed, such as implementing new programs. It can minimize program failures, and implementing digital literacy can succeed and on target.
\end{abstract}

Keywords: Communication, Social Entrepreneurship, MSMEs

\section{INTRODUCTION}

Information and Communication Technology (ICT) is significant for developing human resources in various villages in the current digital era. ICT has been used as a strategy to build villages. In its development, rural development through digital-based technology is considered to provide fundamental changes, especially quality improvements in the social, economic, political, and cultural sectors. In taking out a more optimal village development, it is necessary to be innovative and smart by using assets or resources that are more well organized and provide progress. Therefore, the government realizes this through Law no. 6 of 2014 concerning Villages, which mandates that villages have the right to access information through the village information system developed by the district/city government. 
Through the law on villages, the paradigm of village development has begun to be changed, and development is no longer centered on infrastructure and rural communities' development. One of the efforts to empower village communities is to open the community's broadest possible access to information. Access to information is currently the primary provider for development, in addition to adequate infrastructure (Khusna, 2019).

Apart from the government's efforts, various communities are moving to address this development, one of which is a nonprofit organization called the Kampung Teknologi Foundation (KTF). Kampung Teknologi Foundation is a non-profit organization that focuses on empowering digital literacy or Information and Communication Technology (ICT) to improve Indonesian people's competence in the era of industrial revolution 4.0. KTF always collaborates with the community, government, companies, and other stakeholders to bring Indonesians to be technology literate and digitally aware.

The term digital literacy was leading put forward by Paul Gilster (1997) to understand and use information from various digital sources (Kurnianingsih, Rosini, and Ismayati, 2017). Kampung Teknologi Foundation also organizes various free social activities to improve the quality of human resources in information and communication technology. Of course, it is fully supported by donors and cooperation from both corporations and non-governmental organizations. Through the concept of a digital village that is one of the programs to reduce the gap in the flow of information in villages, KTF uses integrated information and communication technology in public services and economic activities, including for MSME players in marketing their products. For example, the marketing communication method that was previously traditional and conventional has now been integrated into the digital world (Suwatno, 2017).
Marketing communication in digital, is a sales tactic carried out with an online system to produce a practical and maximum impact on product sales. Doing business by utilizing digital internet access through social media, websites, and e-commerce applications are carried out to connect with customers and potential customers more quickly and easily (Maulidasari, and Setiyana, 2020). In this case, digital marketing makes it easy for entrepreneurs to monitor and provide all the needs and desires of potential customers, on the other hand, potential customers can also search for and get product information just by exploring the virtual world, making the search process more comfortable. Digital marketing can reach all people wherever they are without any geographic or time restrictions (Sulaksono, and Zakaria, 2020).

Unfortunately, according to the Director of Information and Communication for the Economy, he revealed that in 2020 out of a total of 60 million MSMEs in Indonesia, only 9.4 million MSMEs managed to go online. There are still few MSME players in Indonesia who use IT, which is an obstacle to their development even though the use of the internet allows MSMEs to do marketing with global market objectives (Basry, and Sari, 2018).

In Indonesia, COVID-19 has brought significant changes in various aspects of human life, including in the economic sector. The increasing spread of the COVID-19 virus that hit the Indonesian economy has resulted in a decline in market mechanisms. It has also happened and felt by some local Indonesian MSME actors. As the heart of the economy, MSMEs or Micro, Small, and Medium Enterprises are among the government's essential priority sectors in the country's economic development.

The Ministry of Cooperatives and Small and Medium Enterprises stated that currently around 37,000 MSMEs are experiencing a severe impact during the COVID-19 period. $4 \%$ of them reported 
difficulties in obtaining raw materials. About $15 \%$ reported disruption of distribution of goods. $22 \%$ reported capital problems. Finally, $56 \%$ of them have experienced a decline in sales. It is because sales of products previously relied on faceto-face or physical meetings between sellers and buyers so the MSME sector has difficulty adapting.

Although the previous history has shown that MSMEs in Indonesia still exist and contribute to the national economy's stability during the economic crisis in 19971998 (Salahudin, Wahyudi, Ulum, and Kurniawan, 2018), however, according to the Ministry of Finance (Kemenku), currently, the business sector that has been significantly affected are MSMEs. Even economic growth can be depressed to a level of $2.5 \%$ to $0 \%$. It can happen if a reasonable and appropriate prevention strategy is not implemented to overcome this (Hanoatubun, 2020).

As a non-profit organization, Kampung Teknologi Foundation (KTF) won the 2017 ITU Global Award in Busan, South Korea, for Best Social Impact (Marketing Agency For SME). KTF has a program that wants Indonesian MSME players to advance their business further digitally. Through training conducted by KTF aimed at business actors, including MSMEs in Indonesia, they are ready to open a business to the next level, digital. Therefore, to develop the economy both on a micro, small and medium scale, a massive innovation and evaluation is currently needed to survive and compete with others. One way that can be done is to carry out social innovation by changing the sales system using digital technology. Digital technology is an essential element needed in the world of entrepreneurship during the COVID-19 pandemic.

Social innovation is closely related to social entrepreneurship. Social innovation is the foundation for a social entrepreneur running a business or activities to seek opportunities, improve systems, find new approaches and create solutions to better environmental changes (Widiastusy, 2011). A social entrepreneur looks for innovative ways to ensure that his business will have access to the resources needed as long as they can create social value (Mort \& Weerawardena, 2003).

According to N. Choi and Majumdar, social innovation is a new solution (products, services, models, markets, processes, etc.) that simultaneously meets social needs (more effectively than existing solutions) and leads to new capabilities and relationships (Majumdar, Satyajit, Guha, Samapti, Marakkath, Nadiya, 2015). Of course, the results of previous research conducted by Safi'i, Widodo, and Pangastuti (2020), it shows that three risks enter at a high level, namely a decrease in the amount of income, a decrease in the amount of production, and an increase in the price of primary raw materials and one risk at a moderate level, namely a delay. Delivery of raw materials can be done with a financial strategy, resizing, finding new markets with social media help, and collaborating with the local government to help with marketing the social service program, which is very intensively carried out.

The research results reinforce this by Maulidasari and Setiyana (2020), which show that there are still many MSME actors who close themselves to developing. They continue to do conventional marketing, selling their products to consumers around their market area. Whereas with the current development of information technology, MSME players should prioritize innovation, market renewal, and orientation that are carried out globally, considering these factors determine the competition in the global market.

So, from some of these studies, the previous author only focused on risk analysis arising from the impact of COVID19 and the socialization of digital technology, did not examine how local governments and economic observers 
helped MSME players transform using digital technology during this Pandemic. Therefore, the author is interested in finding out more about how the social entrepreneurship communication of $\mathrm{ktf}$ through the digital literacy of MSMEs during the covid-19 pandemic.

\section{RESEARCH METHODS}

The method in this study used qualitative research. Qualitative research intends to understand the phenomena experienced by research subjects (Moleong, 2017). We used a qualitative approach with case studies because researchers wanted to reveal and know more deeply about the Kampung Teknologi Foundation's innovations in helping the marketing of MSME products through Digital Literacy by the Kampung Teknologi Foundation during the COVID-19 pandemic. This study was conducted on Instagram and direct observation in Tugu Village, RT 001/005. Cimanggis, Depok, West Java, This study was conducted in March 2020 - November 2020 because it is time for COVID-19 to take place and which was crucial for the decline in sales of the MSME sector.

In data collection techniques, observation aims to obtain data sources and research objects. Furthermore, conducting semi-structured interviews with the Kampung Teknologi Foundation team, mentors or partners from the Kampung Teknologi Foundation, and MSMEs players. And then, this study also used documentation techniques. The documents required are written documents relating to implementing the Kampung Teknologi Foundation's digital literacy program in video screenshots, hands-out material, and others.

\section{RESULTS AND DISCUSSION}

The use of technology is one of the most significant factors in the process of economic growth. Marketing trends that shift from conventional (offline) to digital (online) are often considered more effective and prospective because it is easier to get potential customers from the internet. This change is driven by advances in communication technology that increase interactive communication via digital media to allow the reciprocal flow of information while participating and modifying messages in real-time. In addition, the use of ICT, especially in the field of digital marketing, can enhance business transformation through the speed, accuracy, and efficiency of exchanging large amounts of information.

In the use of Information and Communication Technology (ICT), the government and observers of the economy have an essential role in developing and developing this field. The government's role and support in introducing ICT to business actors can assist the economic sector in running its economy. Unfortunately, the government's role in this matter is still far from optimal. Therefore, to continue and develop economic stability in Indonesia, economic observers are also required to assist the government in making changes to increase the competitiveness of MSME entrepreneurs, as was done by the Kampung Teknologi Foundation (KTF) for MSME players through digital literacy.

The following reasons for the presence of Kampung Teknologi Foundation, according to Mr. Aji as a Founder, ss a legal entity, the KTF is known on behalf of the Kampung Teknologi Foundation. The background has initially been back in 2009 when Facebook just entered Indonesia. Maybe it was just known and started to become popular. We used to have discussions with friends on the Facebook group, seeing the reality that Indonesia's digital divide is relatively high.

Digital literacy can be the ability to understand and use digital devices as a form of mediated communication in various aspects of everyday life. ICT plays a significant role in the economic sector, especially with several business actors who have used digital technology and the cheaper internet connection. In the view of 
the Kampung Teknologi Foundation, digital literacy refers to how this community is willing and able to implement digital technology quickly, and of course, they have to keep abreast of the developments of different times and customs. Of course, digital education must also adapt to regional biographies because it is not sure that it can immediately initiate the digital world in one area. Therefore, there must be local cultural values that are respected in the implementation of technology.

As for this research, it is known that the problem of MSMEs currently lies in the use of digital technology. Many MSME players have not used digital media for marketing because it helps them inform and interact directly with consumers. Unfortunately, this contrasts with government regulations that existed during the COVID-19 pandemic, making consumers switch to using an online purchasing system. Regarding market reach, it is necessary to have the right channel media. MSME actors have not supported the process of delivering information to target customers.

Even though the COVID-19 pandemic situation presents a challenge and an opportunity for the government to maintain the existence of MSMEs, a short-term solution is needed to help MSMEs make sales easier. This solution must be done if related to the digital era, which requires digital technology to support economic activity, and Kampung Teknologi Foundation has done through their social entrepreneurship communication.

Social entrepreneurship is "innovative, creating social value activities in achieving the mission. An organization with an entrepreneurial element shows the ability to create new efforts to provide all social needs. Social entrepreneurship's conceptual, social innovation consists of three processes: formalization, change processes, and the dimensions of social outcomes. Therefore, the Kampung Teknologi Foundation (KTF) holds various digital literacy activities to support MSME players going digital.
In the formalization process or the first stage, what was done by the KTF was also related to Law Number 6 of 2014 concerning Villages, the General Provisions of Article 1 paragraph 12, which read: Village Community Empowerment is an effort to develop community independence and welfare by increasing knowledge, attitudes, skills, behavior, abilities, awareness, and utilizing resources through the establishment of policies, programs, activities, and assistance by the essence of problems and priority needs of the Village community.

In this law, the government is indeed obliged to be present to meet all Indonesian people's needs. However, in reality, many things may not be implemented in some villages, maybe because the infrastructure is inadequate, maybe it could be possible connections. The internet does not exist in that village yet, so the KTF concept, like the one in Depok, should be implemented in several villages that need to advance in implementing digital technology. Therefore, Kampung Teknologi initiated the empowerment of MSMEs in the village by introducing digital sales using social media, market places, e-commerce, and other digital applications. The founder of the Kampung Teknologi Foundation revealed:

We introduce several platforms that they did not know before, that is one of the innovations that we bring to Depok city, like the gojek, gofood, pesona nusantara, Qasir, and Jaman Now.

At this stage, MSME players are also allowed to create special groups and send product catalogs to their loyal customers. Several MSME players collaborate with marketplaces to sell their products throughout Indonesia. It includes utilizing large and local marketplace platforms in Indonesia. So that in this first stage, it is hoped that MSME players will not only know digital media, they will be able to synergize more deeply with their daily activities, primarily to support their productive business activities. 


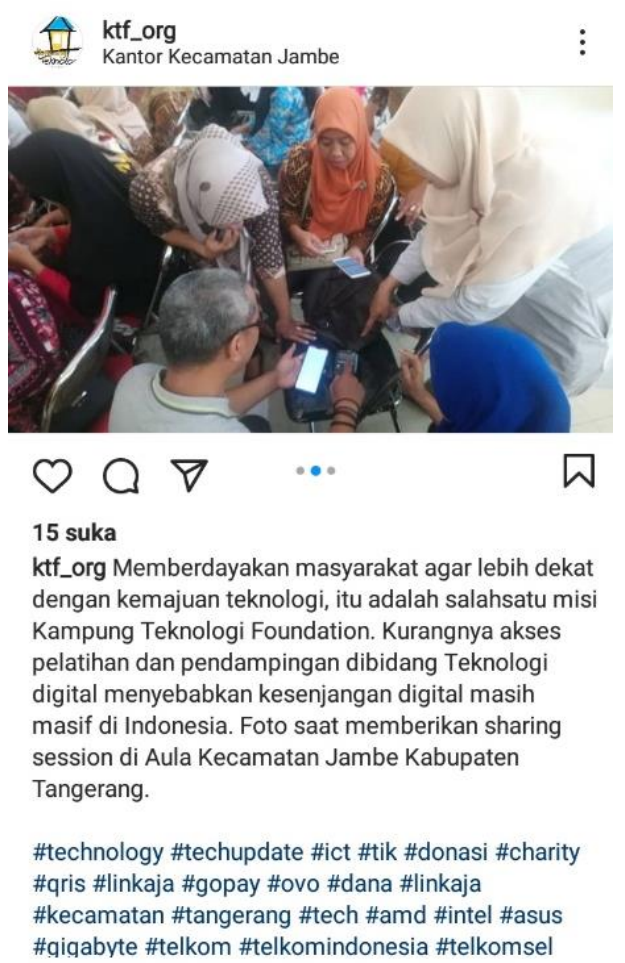

Figure 1. Sharing Session in Offline Training of KTF

Then in social change, the application of digital literacy by the Kampung Teknologi Foundation was carried out starting from preparing and selecting media and making sounding activities. In determining the media, the KTF also initiated a project or program entitled digital up. Digital up is an entrepreneur empowerment program implemented after five years of KTF contributing to digital literacy. In digital up itself, several technological concepts should be implemented by the community, especially entrepreneurs.

1. Implementing google technology, such as google map, google contact photo, etc. In this case, entrepreneurs must be able to use online meeting rooms or use online media. For example, entrepreneurs or MSMEs can use google technology to find business names on the google map.

2. After successfully learning the primary material, MSME players must be masters in the online market. It is related to how these entrepreneurs can market their products through a marketplace or create their online store using a landing page.

3. They are using financial technology. Financial technology is one of the innovations in the financial sector that refers to modern technology. In financial technology, entrepreneurs or the public can implement digital wallets, facilitating cashless payments, access to capital, using digital bank accounts, or maybe investing digitally. Several techniques can be used in financial technology during a pandemic, such as changing the cash payment system to non-cash via a digital wallet. Digital wallets are a means of preventing the transmission of COVID-19 because payments can be made by scanning via cellphone. Things like that are implemented at the third level.

4. It is using digital applications that help finance and sales transactions. For example, general OS applications or maybe general accounting applications, entrepreneurs can take advantage of these applications. Some point of sale applications are free and can be downloaded quickly, such as the Qasir application. Qasir is a point of sale (POS) application that supports a digital cashier system, features product and inventory management, sales reports, digital payments. For business actors or MSMEs, many aspects need to be taken into account financially. A business unit cannot rely on one aspect alone but on managing the paradox between others and integrating practically in marketing and finance. How to be a professional with an entrepreneurial spirit, be creative and productive, etc.

5. Create creative content. MSME players who want to socialize online or carry out marketing communications with 
their customers need creative content. Creative content is one of the tricks that can be used to win the hearts of customers. Creative content influences consumers. In creating creative content, the consistency of a brand needs to be upheld. Because this is what will make a business or product better known, to facilitate this, digitally creative content can be created using free applications, the Canva website, or application.

The development of MSMEs is an essential component in the national development program to lay the foundation for sustainable and equitable economic development. The development of MSMEs is essentially a shared responsibility between the government and the community. Besides, in the face of an increasingly open and competitive market mechanism, mastery of techniques is a prerequisite for increasing MSMEs' competitiveness.

Finally in the last stage in social innovation is exploring the goals and ends of social innovation. After carrying out the formalization stage and the change process, it will produce a third stage, namely social outcomes.

Although Kampung Teknologi Foundation (KTF) has implemented digital literacy may not be that $100 \%$ of MSME actors want to re-implement it during the COVID-19 pandemic, but some of them have succeeded in switching to digital technology. The leading digital media platforms used are the marketplace and ecommerce. These two types of platforms are websites or applications created to facilitate the buying and selling process between sellers and buyers in one place and are most familiar to them.

Even though they consider digital technology quite tricky in the business world, some MSME players have also started using digital financial applications. Some of them include payments using digital payments such as shoppe pay and funds, like Ovo. Users usually only provide
$\mathrm{QR}$, and later the code can go directly to the business actor's account.

\section{CONCLUSION}

Information and Communication Technology (ICT) is significant for developing human resources in various villages in the current digital era. It is also the concern of the Kampung Teknologi Foundation or KTF. KTF is a non-profit organization that focuses on empowering digital literacy or information and communication technology (ICT) to improve Indonesian MSMEs' competence in the digital era. In social entrepreneurship communication, KTF carries out three essential stages, 1) Formalization stage: KTF uses Law No. 6 of 2014 concerning Villages as a basis for empowering MSMEs. Then KTF initiated the empowerment of MSMEs in villages by introducing digital sales using social media, market places, ecommerce, and other digital applications; 2) Change Processes: KTF implemented digital sales by initiating the Digital Up program, which is an entrepreneur empowerment program and was implemented after five-year KTF contributes to digital literacy; 3) Social Outcomes: In the application of digital literacy, only $30 \%$ of MSMEs have successfully switched to using digital technology.

Therefore, good cooperation between one division and another is still needed, such as implementing new programs. It can minimize program failures, and implementing digital literacy can succeed and on target.

\section{REFERENCES}

Basry, Asril, \& Sari, E., M. (2018). Penggunaan Teknologi Informasi dan Komunikasi (TIK) Pada Usaha Mikro, Kecil dan Menengah (UMKM). IKRAITH INFORMATIKA, 2(3).

Kurnianingsih, Rosini, \& Ismayati N. (2017). Upaya Peningkatan 
Kemampuan Literasi Digital bagi Tenaga Perpustakaan Sekolah dan Guru di Wilayah Jakarta Pusat Melalui Pelatihan Literasi Informasi. Jurnal Pengabdian kepada Masyarakat, 3(1).

Majumdar S., Guha, Samapti, \& Marakkath, Nadiya. (2015). Technology and Innovation for Social Change. Spinger Edition: Berlin.

Maulidasari, Setiyana. (2020). Sosialisasi Digital Marketing pada Usaha Mikro Kecil Menengah (UMKM). Jurnal Pengabdian Masyarakat: Darma Bakti Teuku Umar, 2(1).

Moleong, Lexy J. (2017). Metodologi Penelitian Kualitatif. Bandung: PT Remaja Pustaka.

Mort, Gillian Sullivan, \& Jay Weerawardena. (2003). Social Entrepreneurship: towards conceptuali sation. International Journal of Nonprofit and Voluntary Sector Marketing.

Salahudin, Wahyudi, Ulum, \& Kurniawan. (2018). Model Manajemen kelompok Usaha Mikro Kecil dan Menengah (UMKM) Usaha Tepung Tapioka. ARISTO Journal, 6(1).

Sulaksono, J., \& Zakaria N. (2020). Peranan Digital Marketing Bagi Usaha Mikro, Kecil, Dan Menengah (UMKM) Desa Tales Kabupaten Kediri. Generation Journal, 4(1).

Suwatno. (2017). Komunikasi Pemasaran Kontekstual. Bandung: Simbiosa Rekatama Media.

Widiastusy, Ratna \& Meily Margaretha. (2011). Socio Entrepreneurship: Tinjauan Teori dan Perannya Bagi Masyarakat. Jurnal Manajemen Universitas Kristen Maranatha.
Undang-Undang No. 6 Tahun 2014 Tentang Desa. 